\title{
KONSUMSI SIRIH PINANG DAN PATOLOGI GIGI PADA MASYARAKAT PRASEJARAH LEWOLEBA DAN LIANG BUA, DI NUSA TENGGARA TIMUR, INDONESIA
}

\section{BETEL QUID COMSUMPTION AND DENTAL PATHOLOGY AT EAST NUSA TENGGARA'S LEWOLEBA AND LIANG BUA PREHISTORIC COMMUNITIES}

\author{
Toetik Koesbardiati ${ }^{*}$, Delta Bayu Murti ${ }^{2}$ \\ Fakultas Ilmu Sosial dan Ilmu Politik, Universitas Airlangga, Indonesia ${ }^{1,2}$ \\ Toetik.koesbardiati@fisip.unair.ac.id
}

\begin{abstract}
This paper focus on chewing betel quid habit that dominantly happen in the Asia to Pacific region. Betel quid leaves traces of reddish-brown colour on the teeth. It is identified that dental stain was very common on teeth of prehistoric skeletal remains, for example in Thailand and Vietnam. Several studies have shown that chewing betel nut can cause diseases in the teeth and oral cavity. The purpose of this study is to describe the relationship between betel nut chewing and the emergence of tooth pathology in teeth from the prehistoric population from Lewoleba and Liang Bua. Ten individuals were observed using the macroscopic method. The results showed that consumption of betel nut (based on dental stains) was followed by attrition, periodontitis and even antemortem tooth loss.
\end{abstract}

Keywords: Betel quid; dental attrition; periodontitis; AMTL; Liang Bua; Lewoleba

\section{ABSTRAK}

Mengkonsumsi sirih pinang adalah kebiasaan di wilayah Asia hingga Pasifik. Sirih pinang menyisakan jejak warna coklat kemerahan (dental stain) pada gigi geligi. Dental stain banyak diidentifikasi pada gigi geligi sisa rangka prasejarah, misalnya di Thailand dan Vietnam. Beberapa penelitian menunjukkan bahwa mengunyah sirih pinang dapat mengakibatkan penyakit pada gigi dan rongga mulut. Tujuan penelitian ini adalah untuk mendeskripsikan hubungan mengkonsumsi sirih pinang dengan timbulnya patologi gigi geligi pada gigi geligi dari rangka prasejarah masyarakat Lewoleba dan Liang Bua. Sebanyak 10 individu diperiksa dengan menggunakan metode makroskopik. Hasil penelitian menunjukkan bahwa konsumsi sirih pinang (berdasarkan dental stain) diikuti dengan atrisi, periodontitis bahkan antemortem tooth loss.

Kata kunci: Sirih pinang; dental atrisi; periodontitis; AMTL; Liang Bua; Lewoleba

$\begin{array}{ll}\text { Artikel Masuk } & : 13-08-2019 \\ \text { Artikel Diterima } & : 04-11-2019\end{array}$ 


\section{PENDAHULUAN}

Mengunyah sirih pinang adalah kebiasaan yang sudah berlangsung sejak lama di Asia, terutama Asia Tenggara sampai dengan Asia Pasifik. Saat ini kebiasaan mengunyah sirih pinang masih dilakukan di beberapa Negara Asia. Tidak diketahui dengan jelas kapan kebiasaan ini dimulai, namun beberapa penelitian mengindikasikan bahwa kebiasaan mengunyah sirih pinang telah ada sejak 13000 tahun lalu di Asia Tenggara (Zumborich, 2007-2008, hlm. 96). Berdasar temuan arkeobotani berupa kulit biji-bijian yang diidentifikasi sebagai buah pinang (Areca catechu, L), mengindikasikan bahwa kebiasaan mengkonsumsi sirih pinang telah dimulai pada 5800 BP di bagian Utara New Guinea (Zumbroich, 20072008, hlm. 96). Di Pasifik penggunaan pinang dan kapur sirih telah dimulai sejak 300-900 BP di Kepulauan Mariana. Temuan dalam konteks arkeologis yang membuktikan penggunaan pinang ada di bagian atas Gua Spirit dari Thailand yaitu sekitar 7600 BP (Oxenham, 2002, hlm. 910). Lebih jauh, Oxenham (2002, hlm. 909-915) menyatakan bahwa kebiasaan mengkonsumsi sirih pinang juga sudah ditemukan di beberapa masyarakat prasejarah di Vietnam, misalnya masyarakat Nui Nap di bagian utara Vietnam. Zumbroich menjelaskan bahwa sebaran pinang adalah Pulau Andaman, Malaysia peninsula, Jawa hingga Philipina. Fritzpatrick dkk. (2003, hlm. 59-60) menduga bahwa penggunaan sirih pinang berasal dari kebiasaan di India atau Indonesia

Sebutan sirih pinang merujuk pada satu kumpulan bahan yang terdiri dari sirih, baik daun atau bunganya (Piper betle), pinang (Areca catechu), gambir (Uncaria gambir) dan kapur (Calcium hidroxida/Calcium oxida) serta tembakau (Nicotiana tabacum). Konsumsi sirih pinang di kawasan Asia dan Pasifik sangat beragam. Dilaporkan bahwa masyarakat Taiwan hanya mengkonsumsi buah pinang. Masyarakat Kepulauan Mariana memanfaatkan pinang dan kapurnya. Di wilayah Indonesia, konsumsi sirih pinang menggunakan bahan lengkap, yaitu daun sirih, buah pinang, gambir, maupun kapur sirih. Sirih (Piper betle) biasanya dikonsumsi daun atau buahnya yang mengandung komponen phenol yang tinggi. Sirih memberi sensasi kesegaran.

Selain itu sirih memiliki komponen farmakologi aktif yang sangat bervariasi. Komponen utama ke dua dari sirih pinang adalah buah pinang (Areca cathecu). Pinang sebenarnya adalah biji yang dibungkus dengan sabut. Warna kulitnya hijau saat masih mentah, kemudian berangsur menguning dan berakhir dengan warna merah saat masak. Buah pinang dapat dikonsumsi dalam bentuk kering, bentuk segar dari pohon maupun yang difermentasi. Di Pulau Jawa lebih sering dikonsumsi dalam bentuk pinang segar. Di wilayah timur Indonesia, irisan pinang kering lebih menjadi pilihan yang disukai.

Pada bagian endosperma buah pinang mengandung pyridine alkaloids dan phenolic yang dipercaya berguna sebagai obat. Secara umum pinang memiliki 59 kandungan bahan, misalnya alkaloid, flavonoid, tannin, triterpen dan steroid. Berdasarkan kandungan ini, pinang digolongkan sebagai tanaman berpotensi untuk obat (Wei dkk., 2015, hlm. 341). Arecoline sebagai bagian utama dari alkaloid memberi stimulan pada sistem saraf dan meningkatkan stamina. Warna merah yang dihasilkan dari campuran bahan sirih pinang dapat berfungsi sebagai perlindungan terhadap enamel (Ali dkk., 2011, hlm. 200). Berdasarkan pengamatan dan pengalaman penulis, gambir hanya digunakan di Pulau Jawa 
dan Kalimantan sebagai campuran sirih pinang. Tidak banyak informasi mengenai penggunaan gambir dalam campuran sirih pinang, namun gambir sangat umum digunakan oleh masyarakat Jawa.

Bagian terakhir dari sirih pinang adalah kapur sirih. Ada dua macam kapur sirih yang biasa digunakan sebagai bagian dari sirih pinang. Pertama adalah kapur gamping (Calcium hydroxide - $\mathrm{Ca}(\mathrm{OH}) 2$ yang memberi sensasi segar pada mulut. Kedua adalah kapur dari kerang laut atau koral laut yang diperoleh dengan proses dibakar kemudian ditumbuk halus (Calciumoxide - $\mathrm{CaO}$ ). Di wilayah Thailand dan Vietnam, kapur yang berasal dari kerang lebih banyak disukai karena rasanya yang lebih enak (Zumbroich, 2007-2008, hlm. 94). Masyarakat di wilayah timur Indonesia memiliki preferensi yang sama yaitu lebih menyukai kapur sirih yang berasal dari kerang atau koral laut.

Penggunaan sirih pinang di beberapa daerah Indonesia dibarengi dengan penggunaan tembakau (Gambar 1). Cara mengkonsumsi sirih pinang adalah pinang diambil secukupnya, gambir secukupnya, kapur sirih secukupnya lalu dibungkus dengan daun sirih dan siap dikonsumsi. Daerah Indonesia bagian timur, beberapa masyarakat lebih suka bunga sirih sebagai pengganti daun sirih. Sirih pinang ini kemudian dikunyah hingga lumat di dalam mulut. Sirih pinang yang ditumbuk kadangkala masih dijumpai di Jawa. Untuk memulas hasil kunyahan sirih pinang ke seluruh permukaan gigi digunakan tembakau. Akibatnya seluruh gigi akan berwarna coklat kemerahan. Semakin intensif kebiasaan mengunyah sirih pinang semakin pekat warna merah pada gigi. Bahkan diduga warna hasil sirih pinang akan terserap hingga akar gigi. Di Jawa, sirih pinang beserta tembakau kadang diletakkan di mulut di antara pipi dan gigi. Hal ini bisa berlangsung lama. Hasil kunyahan kadang dihisap lalu ditelan, atau diludahkan.

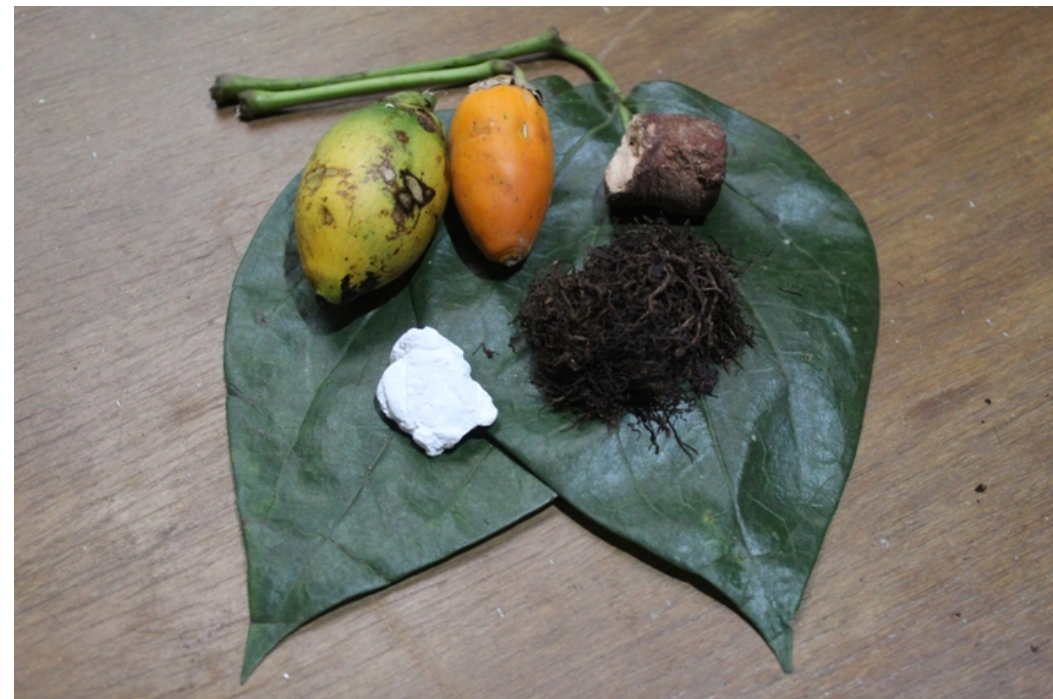

Gambar 1. Bahan Sirih Pinang (Daun Sirih, Buah Pinang, Gambir, Kapur, Tembakau) (Sumber: Foto Koleksi Pribadi) 
Mengunyah sirih pinang adalah kebiasaan yang paling umum dilakukan oleh manusia setelah kebiasaan merokok dan meminum kopi. Mengunyah sirih pinang dapat melepaskan komponen biologis aktif yang menghasilkan efek fisiologis dan respons psikosomatis. Sensasi yang dihasilkan dari sirih pinang adalah rasa nyaman, temperatur tubuh menghangat, perbaikan pencernaan dan peningkatan stamina (Zumbroich, 2007-2008, hlm. 90).

Sirih pinang memiliki makna sosial budaya yang tinggi di wilayah Asia Pasifik. Di dalam peristiwa-peristiwa penting seperti perkawinan atau ritual-ritual adat, sirih pinang menjadi persyaratan utama sebagai tanda keabsahan. Di beberapa kultur, misalnya di Jawa atau Nusa Tenggara Timur, sirih pinang memiliki makna sosial dan hubungan struktural yang tidak bisa diabaikan. Sirih pinang selalu wajib disajikan saat masyarakat melaksanakan ritual ataupun saat masyarakat berkumpul dan bersosialisasi. Terkait dengan kehidupan sosial, diduga sirih pinang juga bermakna kecantikan dan gaya hidup, dalam hal ini adalah warna merah yang dihasilkan yang dapat mewarnai gigi dan bibir si pemakai. Di India dan sebagian Asia Tenggara, sirih pinang berkaitan dengan religi yang dilakukan dalam kehidupan sehari-hari.

Beberapa etnis, sirih pinang dikenal memiliki khasiat sebagai obat yang ajaib karena dapat menyembuhkan berbagai penyakit, misalnya mengurangi rasa sakit, mengurangi demam, menguatkan gigi. Dalam pengobatan tradisional sirih mengandung anti bakteri sehingga seringkali digunakan sebagai pembersih luka, obat sakit gigi. Demikian pula pinang yang mempunyai khasiat anti parasit, anti depresi, anti kelelahan, anti hipertensi, anti oksidan, anti bakteri, anti jamur, anti inflamasi, analgesik, anti alergi, dan persoalan pencernaan serta kadar gula yang tinggi (Wei, 2015, hlm. 341, 350).

Selain efek positif yang dihasilkan dari konsumsi sirih pinang, beberapa laporan penelitian menyebutkan bahwa konsumsi sirih pinang memiliki efek tidak baik terhadap kesehatan mulut dan gigi. WHO (2012, hlm. 15) bahkan memperingatkan untuk tidak mengkonsumsi sirih pinang karena sirih pinang dapat menyebabkan kanker mulut. Efek negatif akan semakin besar jika konsumsi sirih pinang dikombinasikan dengan penggunaan tembakau. Himbauan yang sama disampaikan oleh Public Health Law Center (2017, hlm. 5) yang menyatakan bahwa mengunyah sirih pinang baik dengan atau tanpa tembakau dapat memicu berbagai jenis kanker, misalnya kanker bibir, kanker mulut, kanker lidah, kanker pharinx, kanker esophagus, kanker perut, prostat, cervix dan kanker paru.

Lebih jauh efek dari mengunyah sirih pinang adalah rusaknya jaringan keras dari gigi, termasuk gigi, jaringan penyokong periodontal, sendi tempromandibular dan jaringan lunak sekitar gigi. Konsumsi sirih pinang yang sudah menjadi kebiasaan dalam waktu yang lama dapat mengakibatkan atrisi, abrasi kerusakan gigi, pewarnaan gigi, dan penyakit periodontal seperti iritasi gusi dan longgarnya jaringan penyangga gigi. Chatrchaiwiwatana (dalam Hsiao dkk., 2015, hlm. 307) mengungkapkan bahwa mengunyah pinang dapat mengurangi resiko dental karies. Tetapi dalam jangka lama, calculus yang diproduksi oleh kunyahan sirih pinang dapat mengakibatkan periodontitis. Hasil studi Hsiao dkk. (2015, hlm. 300-308), menunjukkan bahwa resiko gigi tanggal akibat periodontitis lebih tinggi pada pengunyah pinang dibanding dengan yang tidak mengkonsumsi pinang. 
Informasi di atas menunjukkan bahwa sirih pinang adalah bagian dari cultural belief yang sudah melekat dalam kehidupan sehari-hari pada masyarakat di Asia, Pasifik bahkan migran yang berada di Eropa dan Amerika. Hingga saat ini mengunyah sirih pinang masih merupakan keseharian sebagai bagian dari kehidupan masyarakat.

Maksud penelitian ini adalah untuk mendeskripsikan kebiasaan memakan sirih pinang pada masyarakat prasejarah. Tujuan penelitian ini adalah untuk menjelaskan apakah ada keterkaitan antara mengunyah sirih pinang dengan kesehatan gigi geligi. Mengingat bahwa sirih pinang sudah dimanfaatkan sejak masa prasejarah (misal di Vietnam dan Thailand), diduga bahwa sirih pinang juga sudah dikonsumsi oleh masyarakat prasejarah dari Lewoleba dan Liang Bua, Nusa Tenggara Indonesia, yang ditandai dengan adanya pewarnaan (dental stain) pada gigi geligi mereka. Berdasarkan indikasi konsumsi sirih pinang ini kemudian dicari hubungan apakah konsumsi sirih pinang berhubungan dengan kesehatan terutama patologi pada gigi, dibuktikan dari frekuensi kemunculan patologinya. Yang dimaksud patologi disini adalah periodontitis, antermortem tooth loss, atrisi, karies, abses, dan kalkulus. Dengan kata lain, masalah yang akan dibahas dalam penelitian ini adalah apakah konsumsi sirih pinang berpengaruh terhadap kesehatan gigi, dalam hal ini periodontitis, atrisi, karies, antemortem tooth loss, abses, dan kalkulus yang dapat diamati pada sisa rangka manusia.

\section{METODE}

Bahan penelitian ini adalah sisa rangka manusia prasejarah yang berasal dari Lewoleba (Pulau Lembata, Flores) dan Liang Bua, (Pulau Flores) di Nusa Tenggara Timur. Fokus materi penelitian adalah gigi geligi dari sisa rangka manusia prasejarah. Sisa rangka masyarakat prasejarah dari Lewoleba berasal dari penggalian pertama yang dilakukan oleh Th. Verhoeven pada tahun 1961 bersama Sukadana (Lie, 1965, hlm. 609-624). Lokasi utama penggalian adalah di Lewoleba dengan kode LL I. Dari penggalian ini dihasilkan 5 rangka (LL I.1, LL I.2, LL I.3., LL I.4., dan LL I.5). Berdasarkan hasil analisis C14 terhadap temuan arang yang ada, didapatkan penanggalan untuk individu Lewoleba adalah $2990 \pm 160$ BP (Centrum voor Isotopen Onderzoek, Groningen, Nederlands (Atmosudiro, 1994, hlm. 305-306).

Sisa rangka masyarakat prasejarah dari Liang Bua adalah hasil penggalian yang dilakukan oleh Th. Verhoeven pada tahun 1965 di dalam Gua di dekat kota Ruteng, Pulau Flores (Murti., 2011, hlm. 62). Keseluruhan hasil penggalian berhasil direkonstruksi sebanyak 5 individu yaitu LB/1, LB/2, LB/3, LB/5 dan LB/6. Hasil penanggalan dari individu Liang Bua (LB/3) adalah 3809 \pm 20 BP berdasarkan tulang tengkoraknya, (LB/6) berdasarkan tulang tengkoraknya adalah $3394 \pm 24 \mathrm{BP}$ (Tokyo University., 2015). Keseluruhan material penelitian berada di Universitas Airlangga. Lokasi penelitian adalah Museum Etnografi dan Pusat Kajian Kematian, Fakultas Ilmu Sosial dan Ilmu Politik, Universitas Airlangga.

Metode yang diterapkan adalah makroskopis, yaitu dengan melakukan pengamatan langsung terhadap materi penelitian. Adapun fokus pengamatan 
adalah gigi geligi dengan tanda adanya bukti dental staining atau dental coloring yaitu pewarnaan gigi sebagai akibat dari aktivitas mengunyah atau mengkonsumsi sirih pinang. Fokus pengamatan patologi gigi geligi adalah adanya patologi gigi geligi yang diduga berkaitan dengan konsumsi sirih pinang. Patologi yang sering disebut sebagai akibat dari konsumsi sirih pinang adalah atrisi, periodontitis, karies dan antemortem tooth loss (Javed dkk., 2013, hlm. 273278; Giri dkk., 2014, hlm. 57-60; Hsiao dkk., 2014, hlm. 133-140; Ling dkk., 2001, hlm. 364-369; Samnieng, 2012, hlm. 107-111).

Atrisi adalah proses fisiologis, ausnya jaringan keras pada gigi sebagai akibat dari kontak antara gigi dengan gigi selama mengunyah dan menelan makanan. Di kalangan populasi prasejarah, atrisi adalah patologi yang paling sering muncul dan paling destruktif terhadap jaringan keras gigi. Selain itu atrisi adalah penyebab utama dari formasi abscess pada jaringan periapical dan periodontal, akar gigi, Antemortem Tooth Loss (AMTL) dan penyakit sendi temporomandibular. Periodontitis adalah proses inflamasi yang secara perlahan merusak ligamen periodontal, cementum dan tulang alveolar sehingga membuat gigi longgar dari soketnya. Secara umum periodontitis berpengaruh terhadap semua gigi, yang ditandai dengan reduksi horisontal pada alveolar maxilla. Reduksi alveolar dan jaringan lunak membuka akar gigi sehingga terpapar oleh cairan mulut. Ketika gigi terbuka dari soketnya akibat pengunyahan bahan yang keras, meningkatkan resiko terjadinya abses dan akhirnya gigi akan tanggal.

Dalam penelitian ini tidak dilakukan kategorisasi tingkat keparahan patologi. Kategorisasi didasarkan pada ada dan absennya patologi yang diduga berkaitan dengan pengunyahan sirih pinang, dalam hal ini adalah ada atau absennya atrisi, karies, kalkulus, periodontitis, maupun AMTL pada setiap individu yang diamati.

Pandangan umum tentang sirih pinang adalah menguatkan gigi atau dengan kata lain membuat gigi sehat dan tidak berlubang. Penelitian ini melihat sisi lain dari aspek mengunyah sirih pinang terhadap patologi gigi. Pemahaman gigi kuat dalam masyarakat bisa jadi tidak sama dengan gigi kuat tetapi pada gigi terdapat kalkulus. Gigi memang tidak berlubang tetapi bisa jadi longgar dalam jaringan gusinya, dan lain sebagainya. Oleh karena itu melihat aspek patologi gigi sangat menarik karena belum menjadi perhatian yang serius terkait konsumsi sirih pinang.

\section{HASIL PENELITIAN}

\section{Deskripsi Individu Dari Lewoleba}

Tengkorak LL I.1. terdiri dari cranium dan mandibula yang kedua bagiannya tertutup matriks. Bagian yang hilang pada tengkorak adalah os parietale kiri dan kanan. Kondisi gigi geligi LL I.1 relative lengkap namun kurang dapat diamati patologi gigi geligi dan pewarnaannya akibat tertutup matriks. Hal yang dapat diamati adalah permukaan oklusal gigi sehingga dapat dikenali atrisi gigi. 
Tabel 1. Temuan gigi geligi pada individu Lewoleba

\begin{tabular}{|c|c|c|c|c|}
\hline No & Individu & nature & Gigi tersisa & Keterangan \\
\hline 1 & LL1.1 & $\begin{array}{l}\text { Maxilla } \\
\text { Mandibula }\end{array}$ & & Tertutup matriks \\
\hline 2 & LL 1.2. & Mandibula & $\begin{array}{l}\mathrm{P}^{1}, \mathrm{P}^{2}, \mathrm{M}^{1}, \mathrm{M}^{2}, \\
\mathrm{M}^{3}-\text { kanan } \\
\mathrm{P}^{1}, \mathrm{M}^{1}, \mathrm{M}^{2}-\mathrm{kiri} \\
\mathrm{C} \text {, dan } \mathrm{P}_{1}- \\
\text { Mandibula kiri }\end{array}$ & $\begin{array}{l}\text { Terdapat dental } \\
\text { stain } \\
\text { Terindikasi } \\
\text { beberapa } \\
\text { patologi gigi }\end{array}$ \\
\hline 3 & LL 1.3 & $\begin{array}{l}\text { Maxilla } \\
\text { Mandibula }\end{array}$ & $\begin{array}{l}\mathrm{P}^{2}, \mathrm{M}^{1}, \mathrm{M}^{2}, \mathrm{M}^{3} .- \\
\text { kanan } \\
\mathrm{P}^{2}, \mathrm{M}^{2}, \mathrm{M}^{3} . \text { - kiri } \\
\mathrm{I} \text {-M3 kiri dan } \\
\text { kanan }\end{array}$ & $\begin{array}{l}\text { Terindikasi } \\
\text { memiliki dental } \\
\text { stain } \\
\text { dan patologi gigi }\end{array}$ \\
\hline 4 & LL 1.4. & & $\begin{array}{l}\mathrm{M}^{1} \text { dan } \mathrm{M}^{3} \\
\text { maxilla kanan } \\
\text { dan kiri. } \\
\mathrm{I}_{2}, \mathrm{C}, \mathrm{M}_{1}, \mathrm{M}_{2}, \mathrm{M}_{3} \text {. } \\
- \text { kanan } \\
\mathrm{M}_{1}, \mathrm{M}_{2}, \mathrm{M}_{3} \text { - - kiri }\end{array}$ & $\begin{array}{l}\text { Terindikasi } \\
\text { dental stain pada } \\
\text { geligi maxilla dan } \\
\text { mandibula dan } \\
\text { patologi gigi }\end{array}$ \\
\hline \multirow[t]{2}{*}{5} & LL 1.5 & Maxilla & $\begin{array}{l}\mathrm{I}^{1}, \mathrm{P}^{2}, \mathrm{M}^{1}, \quad \mathrm{M}^{2} \\
\text { kanan, } \\
\mathrm{I}^{1}, \mathrm{P}^{1}, \mathrm{P}^{2}, \mathrm{M}^{2}, \mathrm{M}^{3} \\
\text { - kiri }\end{array}$ & $\begin{array}{l}\text { Terindikasi } \\
\text { dental stain dan } \\
\text { patologi gigi }\end{array}$ \\
\hline & & Mandibula & $\begin{array}{l}\mathrm{P}_{1}, \quad \mathrm{M}_{1}, \quad \mathrm{M}_{2}- \\
\text { kanan } \\
\mathrm{C}, \mathrm{P}_{1}, \mathrm{P}_{2}, \mathrm{M}_{1}, \mathrm{M}_{2}, \\
\mathrm{M}_{3}-\text { kiri }\end{array}$ & \\
\hline
\end{tabular}

LL I.2. menyisakan cranium dan mandibula. Bagian wajah menyisakan os zygomatic kiri. Mandibula LL I.2. patah pada bagian ramus kanan. Bagian procesus coronoideus kanan hilang. Gigi geligi yang dapat diamati adalah $\mathrm{P}^{1}, \mathrm{P}^{2}, \mathrm{M}^{1}, \mathrm{M}^{2}, \mathrm{M}^{3}$ maxilla kanan dan $\mathrm{P}^{1}, \mathrm{M}^{1}, \mathrm{M}^{2}$ maxilla kiri. Pada bagian mandibula, gigi geligi relatif utuh. Gigi mandibula yang hilang adalah $\mathrm{I}_{2}$ dan $\mathrm{M}_{2}$ kanan, serta $\mathrm{M}_{1}$ kiri. Hasil pengamatan juga menunjukkan adanya bukti pencabutan pada incisivus lateral maxilla. Pada seluruh enamel gigi geligi yang tersisa terdapat pewarnaan gigi yang mengindikasikan adanya praktek mengunyah sirih pinang. Derajat pewarnaan bervariasi, dari yang samar hingga kuat. Diduga hal ini dipengaruhi oleh intensitas mengunyah sirih pinang atau penambahan bahan sirih pinang tertentu yang bergantung pada factor kesukaan individu. Atrisi tampak kuat pada permukaan oklusal gigi terutama gigi geligi molar. Selain atrisi terdapat kalkulus pada gigi $C$ dan $P_{1}$ mandibula kiri dan AMTL pada $M_{1}$ mandibula kiri. Periodontitis dijumpai pada gigi geligi LL I.2.

LL I.3. menyisakan cranium dan mandibula yang keduanya tertutup matrix. Bagian yang pecah/hilang pada cranium adalah bagian os parietale, dan os occipital kiri (Gambar 3). Bagian mandibulanya relative utuh. Bagian mandibula yang hilang adalah procesus coronoideus kiri. Beberapa gigi yang tersisa dari maxilla kanan adalah $\mathrm{P}^{2}, \mathrm{M}^{1}, \mathrm{M}^{2}, \mathrm{M}^{3}$. Sedangkan maxilla sebelah kiri menyisakan $\mathrm{P}^{2}, \mathrm{M}^{2}$, $M^{3}$. Pada mandibula gigi geliginya relalif lengkap. Bagian $P_{1}, P_{2}$ dan $M_{1}$ hanya menyisakan akar giginya. Dari hasil pengamatan menunjukkan bahwa pada gigi geliginya terdapat pewarnaan sebagai hasil mengunyah sirih pinang. Warna yang 
tampak pada individu ini seperti hal nya warna pada geligi dari individu lain yaitu merah kecoklatan.

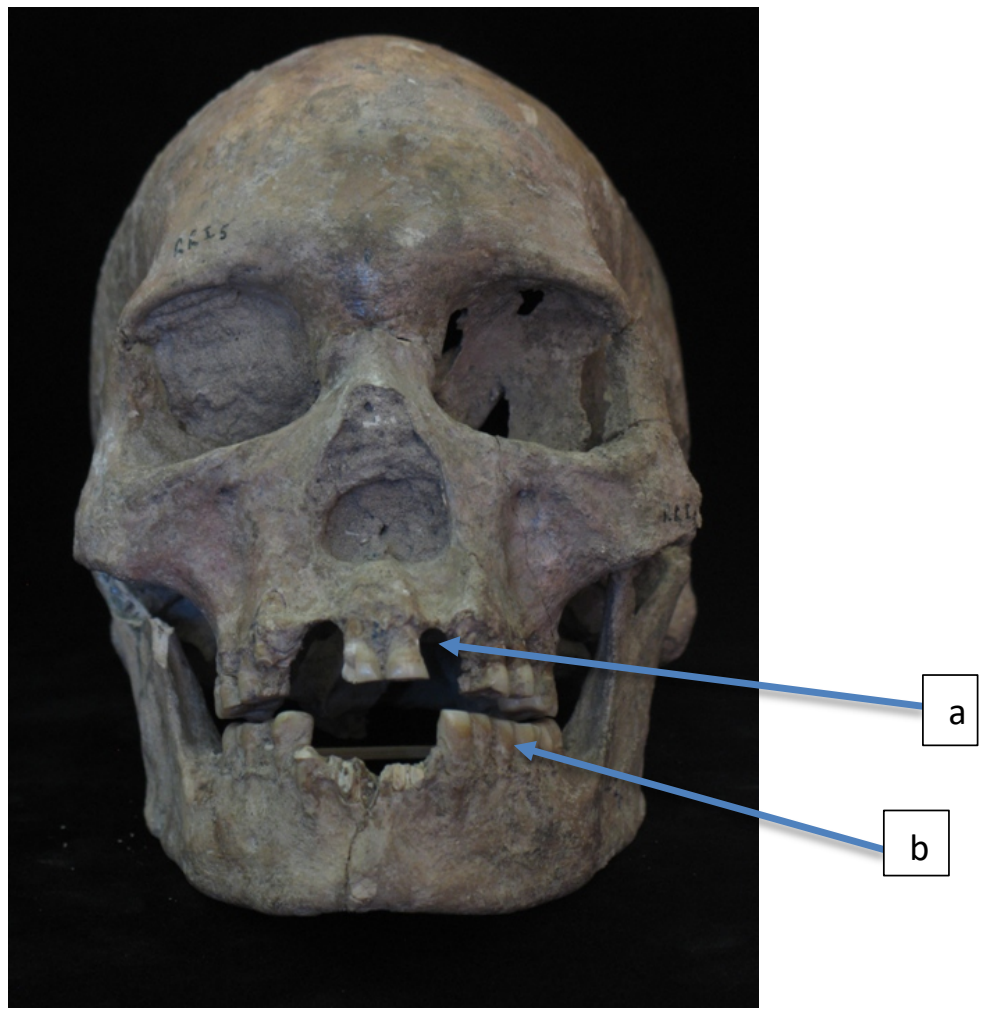

Gambar 2. Individu LL 1.5. A=Praktik modifikasi gigi. B=dental stain (Sumber: Foto Koleksi Pribadi)

Intensitas dan gradasi warna (merah hingga merah kecoklatan) diduga terkait dengan lama dan intensitas mengunyah sirih pinang. Selain itu tampak adanya pencabutan/ablasi pada incisivus lateral maxilla. Pada permukaan oklusal terdapat atrisi yang jelas terutama pada oklusal molarnya.

LL I.4. menyisakan cranium yang relative utuh. Bagian yang hilang dari kranium adalah bagian os nasal dan sebagian os temporal kiri serta arcus zygomatic kiri. Pada bagian mandibula bagian yang absen adalah procesus condylaris kanan. Gigi geligi yang masih dapat diamati adalah $\mathrm{M}^{1}$ dan $\mathrm{M}^{3}$ maxilla kanan dan kiri. Pada mandibula kanan tersisa $\mathrm{I}_{2}, \mathrm{C}, \mathrm{M}_{1}, \mathrm{M}_{2}, \mathrm{M}_{3}$. Sedangkan bagian mandibula kiri dapat diamati $\mathrm{M}_{1}, \mathrm{M}_{2}, \mathrm{M}_{3}$. Pada incisivus lateral maxilla menunjukkan adanya praktik pencabutan/ablasi. Pada enamel gigi geliginya menunjukkan adanya bukti pengunyahan sirih pinang terbukti dari adanya pewarnaan. Warna dihasilkan dari campuran komponen sirih pinang yang jika dikunyah atau diusapkan pada permukaan gigi dengan intensitas tertentu akan menghasilkan pewarnaan pada gigi.

Periodontitis dapat diamati pada sususnan gigi geliginya. Atrisi dapat diamati pada permukaan oklusal $\mathrm{M}^{1}$ maxilla kiri dan kanan, dan mandibula kiri dan kanan. Seperti pola atrisi pada gigi geligi individu LB, LL I.4 juga 
menunjukkan atrisi dengan pola bertendensi miring ke arah lateral. Selain atrisi, kalkulus dapat diamati pada gigi geligi LL I.4.

LL I.5. terdiri dari kranium dan mandibula yang relatif utuh. Bagian yang hilang pada kranium adalah procesus zygomaticus kiri dan kanan (Gambar 2). Pada mandibula bagian procesus coronoideus kanan hilang. Gigi geligi yang masih tersisa adalah $\mathrm{I}^{1}, \mathrm{P}^{2}, \mathrm{M}^{1}, \mathrm{M}^{2}$ pada maxilla kanan, dan $\mathrm{I}^{1}, \mathrm{P}^{1}, \mathrm{P}^{2}, \mathrm{M}^{2}, \mathrm{M}^{3}$ pada maxilla kiri. Pada mandibula, gigi geligi yang tersisa adalah $\mathrm{P}_{1}, \mathrm{M}_{1}, \mathrm{M}_{2}$ bagian kanan dan $\mathrm{C}, \mathrm{P}_{1}$, $\mathrm{P}_{2}, \mathrm{M}_{1}, \mathrm{M}_{2}, \mathrm{M}_{3}$. Hasil pengamatan menunjukkan adanya praktek pencabutan pada bagian incisivus lateral maxilla. Pada bagian enamel geliginya terdapat bukti pewarnaan sebagai akibat dari mengunyah sirih pinang (Gambar 4). Warna dari campuran sirih pinang bercampur dengan saliva (ludah) dan menyebabkan pewarnaan pada gigi. Periodontitis dapat diamati di susunan gigi geliginya. Atrisi gigi geligi tampak pada permukaan oklusal terutama pada molarnya. Terdapat AMTL pada $\mathrm{M}^{1}$ kiri maxilla.

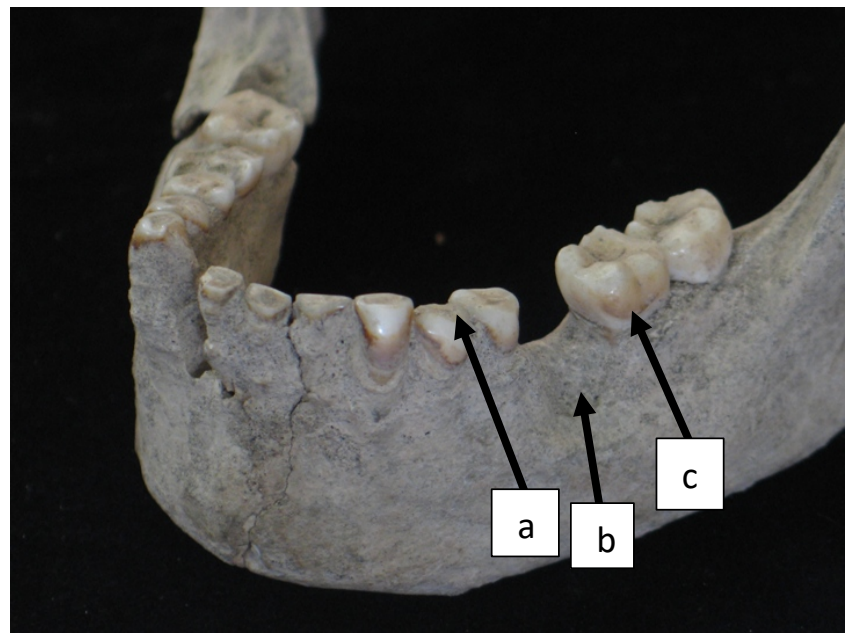

Gambar 3. Individu LL 1.3. A= Atrisi, B=Antemortem Tooth Loss (AMTL) dan C=Pewarnaan (dental stain)

(Sumber: Foto Koleksi Pribadi)

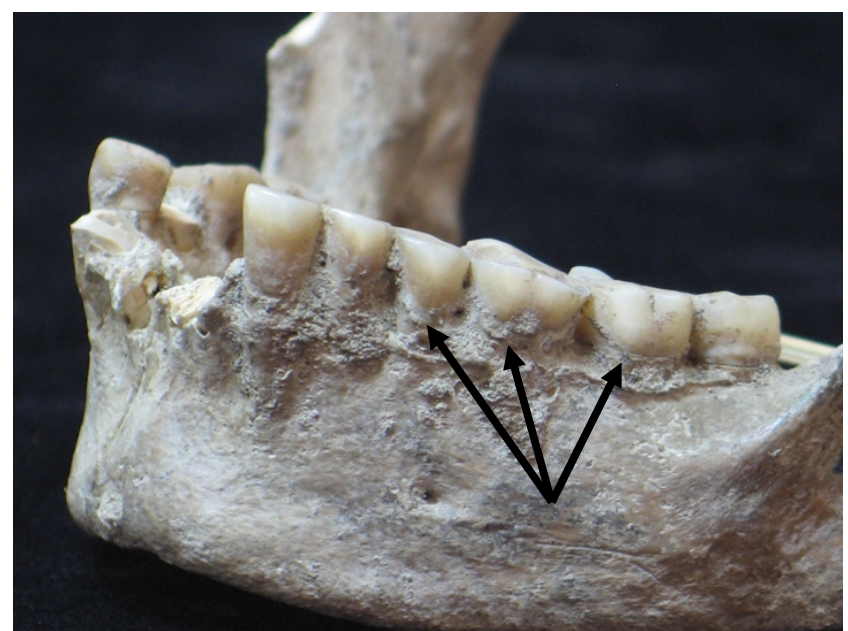

Gambar 4. Individu LL 1.5. Dental Calculus pada bagian yang ditunjuk (Sumber: Foto Koleksi Pribadi) 


\section{Deskripsi Individu Dari Liang Bua}

Kondisi temuan tengkorak LB/1 sangat fragmentaris. Bagian yang tersisa adalah os frontale, os parietale (kiri dan kanan), os occipital, os temporal (kiri dan kanan), os zygomatic dan maxilla kanan. Beberapa gigi geligi yang tersisa adalah $\mathrm{P}^{1}, \mathrm{P}^{2}, \mathrm{M}^{1}, \mathrm{M}^{2}$ (kanan). Sebelah kiri adalah $\mathrm{I}^{1}, \mathrm{P}^{1}, \mathrm{P}^{2}, \mathrm{M}^{1}, \mathrm{M}^{2}$. Namun bagian gigi geligi baik pada maxilla maupun mandibula masih dapat diamati sekalipun tidak lengkap. Mandibula patah di bagian korpus sebelah kanan, tetapi masih tersisa gigi $I_{1}, P_{1}, P_{2}, M_{1}, M_{2}, M_{3}$. Mandibula kiri menyisakan $I_{1}, I_{2}, C, P_{1}, P_{2}, M_{1}, M_{2}$. Sekalipun demikian masih dapat diamati patologi gigi geligi nya. Gigi geligi LB/1 menunjukkan indikasi adanya pewarnaan yang disebabkan dari mengkonsumsi sirih pinang. pewarnaan gigi ini berasal dari campuran komponen sirih pinang yang jika dicampur akan menhasilkan warna merah dan dapat menempel pada gigi bergantung pada intensitas penggunaan sirih pinang. Sekalipun sangat tidak jelas, tetapi pewarnaan dapat diamati di bagian sekitar cingulumnya. Selain pewarnaan, terdapat karies dan kalkulus. Pada permukaan oklusal dapat diamati adanya atrisi. Periodontitis dapat diamati pada gigi geligi LB/1. Hasil pengamatan mengindikasikan adanya praktik pencabutan gigi pada incisivus lateral maxilla. Koesbardiati, dkk. (2015), menyebutkan bahwa masyarakat Liang Bua dan Lewoleba memiliki tradisi modifikasi gigi. Secara umum pola modifikasi yang dilakukan adalah pencabutan atau ablasi. Gigi yang biasa dicabut adalah dua incisivus lateral maxilla. Diduga pencabutan adalah bentuk inisiasi yang dilakukan baik pada laki-laki maupun perempuan.

Tabel 2. Temuan gigi geligi pada individu Liang Bua

\begin{tabular}{|c|c|c|c|c|}
\hline No & Individu & Nature & Gigi yang tersisa & Keterangan \\
\hline 1 & $\mathrm{LB} / 1$ & $\begin{array}{l}\text { Maxilla } \\
\text { Mandibula }\end{array}$ & $\begin{array}{l}\mathrm{P}^{1}, \mathrm{P}^{2}, \mathrm{M}^{1}, \mathrm{M}^{2} \text { kanan } \\
\mathrm{I}^{1}, \mathrm{P}^{1}, \mathrm{P}^{2}, \mathrm{M}^{1}, \mathrm{M}^{2} \text {-kiri } \\
\mathrm{I}_{1}, \mathrm{P}_{1}, \mathrm{P}_{2}, \mathrm{M}_{1}, \mathrm{M}_{2}, \mathrm{M}_{3}- \\
\text { kanan } \\
\mathrm{I}_{1}, \mathrm{I}_{2}, \mathrm{C}, \mathrm{P}_{1}, \mathrm{P}_{2}, \mathrm{M}_{1}, \mathrm{M}_{2}- \\
\text { kiri }\end{array}$ & $\begin{array}{l}\text { Terindikasi } \\
\text { adanya gradasi } \\
\text { dental stain dan } \\
\text { patologi gigi }\end{array}$ \\
\hline 2 & $\mathrm{LB} / 2$ & $\begin{array}{l}\text { Maxilla } \\
\text { Mandibula }\end{array}$ & $\mathrm{I}^{1}, \mathrm{P}^{1}, \mathrm{P}^{2}$ & $\begin{array}{l}\text { Dental stain dan } \\
\text { patologi gigi }\end{array}$ \\
\hline 3 & LB/3 & $\begin{array}{l}\text { Maxilla } \\
\text { Mandibula }\end{array}$ & $\begin{array}{l}\mathrm{I}^{1}-\text { kanan } \\
\mathrm{P}^{1}, \mathrm{P}^{2}, \mathrm{M}^{3}-\text { kiri }\end{array}$ & $\begin{array}{l}\text { Terindikasi } \\
\text { dental stain dan } \\
\text { patologi gigi }\end{array}$ \\
\hline 4 & LB/5 & $\begin{array}{l}\text { Maxilla } \\
\text { Mandibula }\end{array}$ & Gigi lepas M, P dan C & $\begin{array}{l}\text { Terindikasi } \\
\text { dental stain }\end{array}$ \\
\hline 5 & LB/6 & $\begin{array}{l}\text { Maxilla } \\
\text { Mandibula }\end{array}$ & $\begin{array}{l}\mathrm{I}^{1}, \mathrm{C}, \mathrm{P}^{1}, \mathrm{P}^{2}, \mathrm{M}^{1}, \mathrm{M}^{2}, \mathrm{M}^{3}- \\
\text { kanan } \\
\mathrm{I}^{1}, \mathrm{C}, \mathrm{P}^{1}, \mathrm{M}^{1}, \mathrm{M}^{2}, \mathrm{M}^{3} \text { - kiri } \\
\mathrm{P}_{1}, \mathrm{P}_{2}, \mathrm{M}_{1}, \mathrm{M}_{2}, \mathrm{M}_{3} \text {-kanan }\end{array}$ & $\begin{array}{l}\text { Terindikasi } \\
\text { dental stain dan } \\
\text { patologi gigi }\end{array}$ \\
\hline
\end{tabular}

Sumber: Dokumen Pribadi 


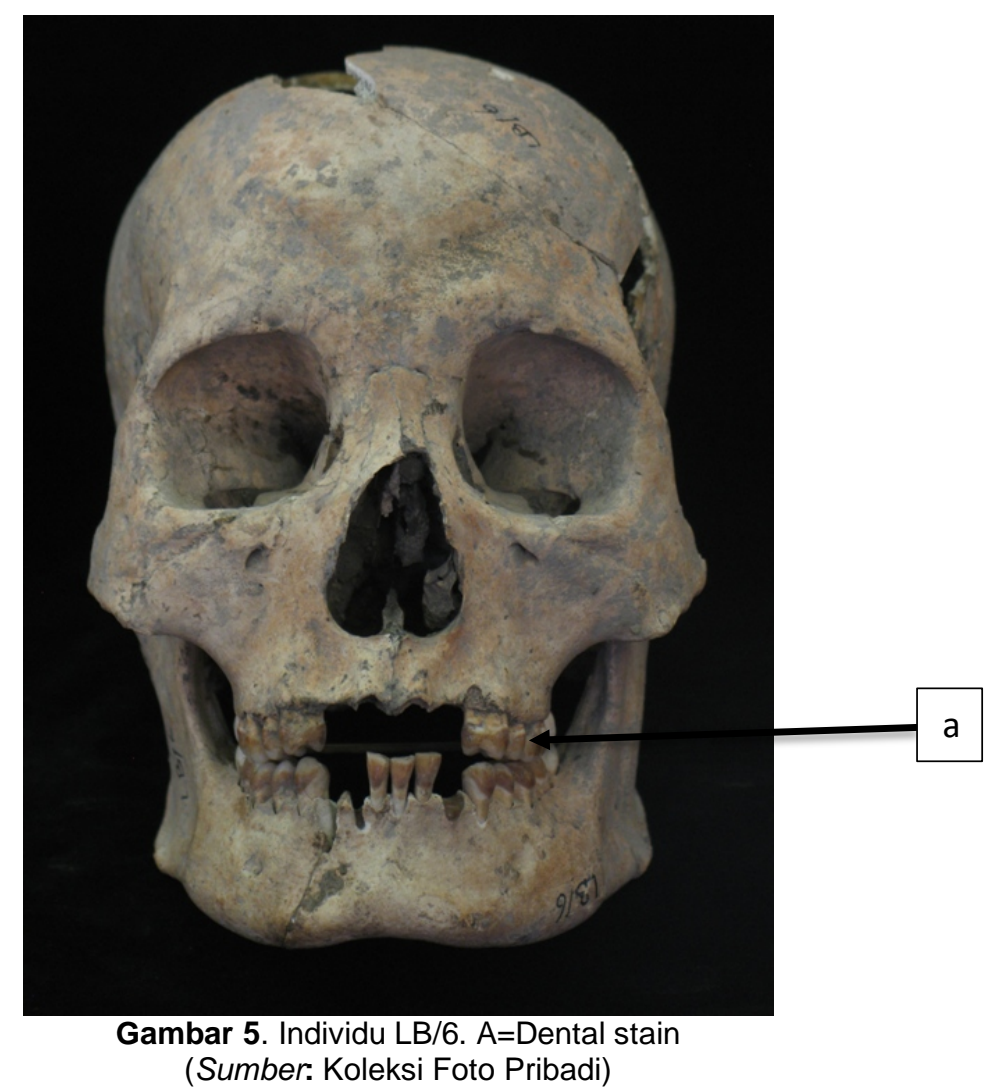

Tengkorak LB/2 sangat fragmentaris. Dari keseluruhan tengkorak, tersisa os frontale (bagian kiri dan kanan), os temporale (kiri dan kanan), os zygomaticum (kiri dan kanan) dan maxilla bagian kanan. Mandibula pecah menjadi dua fragmen, masing-masing bagian menyisakan ramus dan korpus mandibula. Hanya beberapa gigi geligi yang tersisa pada maxilla yaitu $\mathrm{I}^{1}, \mathrm{P}^{1}, \mathrm{P}^{2}$. Berdasarkan absorbsi pada ${ }^{1}$ dan $\mathrm{C}$ pada maxilla diduga bahwa LB/2 mengalami praktek pencabutan (ablasi) pada gigi incisivus lateralnya. Selain itu terdapat pewarnaan pada enamel gigi geliginya, sekalipun sangat tipis. Tebal tipisnya pewarnaan gigi diduga berasal dari intensitas mengunyah dan lama menggunakan sirih pinang. Patologi lain yang dapat diamati adalah atrisi pada permukaan oklusal. Hasil pengamatan lain adalah adanya kalkulus, periodontitis dan karies pada gigi geligi $\mathrm{LB} / 2$.

LB/3 adalah tengkorak dalam kondisi cukup baik dan relatif lengkap. pada bagian basis kraniumnya hilang. Bagian yang tersisa adalah kalvaria, fragmen os zygomatic (kiri dan kanan), os nasal, dan maxilla. Di bagian maxilla kanan tersisa $\mathrm{I}^{1}$, dan $\mathrm{P}^{1}, \mathrm{P}^{2}, \mathrm{M}^{3}$ di sebelah kiri. Hasil pengamatan menunjukkan adanya pencabutan gigi incisivus lateral kiri dan kanan maxilla. Indikasi adanya praktik mengunyah sirih pinang ditandai dari pewarnaan yang tampak jelas pada gigi geliginya, terutama $\mathrm{P}^{1}, \mathrm{P}^{2}$ maxilla dan $\mathrm{I}_{1}, \mathrm{I}_{2}, \mathrm{C}$ pada mandibula kiri dan kanan. Patologi yang dapat diamati adalah atrisi. Atrisi ini bahkan membentuk kemiringan pada gigi anterior secara lateral. Abses ditemukan pada jaringan 
periodontal pada $\mathrm{P}^{1}$ maxilla kiri. LB/3 menunjukkan adanya periodontitis dan antemortem tooth loss yang tampak pada $\mathrm{M}_{1}$ mandibula kiri.

LB/5 adalah tengkorak yang sangat fragmentaris dan paling tidak lengkap. Bagian yang tersisa adalah os zygomatic kanan, fragmen os parietale, dan fragmen os occipital. Gigi geligi yang tersisa adalah gigi lepas yaitu molar, premolar dan caninus. Kondisi gigi geligi ini kurang baik karena sudah mengalamii kerusakan. Sekalipun demikian dapat diidentifikasi adanya pewarnaan pada enamel gigi lepas dari LB/5 yang mengindikasikan bahwa LB/5 mengkonsumsi sirih pinang. Patologi yang dapat diamati adalah adanya atrisi pada permukaan oklusalnya. Indikasi adanya karies dan kalkulus dapat diamati dari gigi geligi yang tersisa. Periodontitis kurang bisa diamati karena kondisi gigi geligi lepas.

LB/ 6 ada dalam kondisi relatif utuh dan lengkap. Beberapa bagian yang hilang pada kranium adalah sebagian os parietale dan os frontale kiri, procesus zygomaticus kiri dan kanan (Gambar 5). Gigi geligi yang absen adalah I' $\mathrm{I}^{2}$, C kiri dan kanan. Di bagian mandibula bagian yang hilang adalah $\mathrm{I}_{2}, \mathrm{C}$ kiri dan $\mathrm{C}$ kanan. Berdasarkan absorbsi pada I ${ }^{2}$ diduga LB/6 melakukan praktik pencabutan/ablasi gigi $\mathrm{I}^{2}$ kiri dan kanan pada maxilla. Pengamatan lain menunjukkan adanya pewarnaan gigi sebagai indikasi mengunyah sirih pinang, yang terlihat di semua enamel gigi geligi yang tersisi dari LB/6. Atrisi pada permukaan oklusal dapat dikenali. Atrisi membentuk pola miring secara lateral pada LB/ 6 pada bagian gigi anterior (Gambar 6).

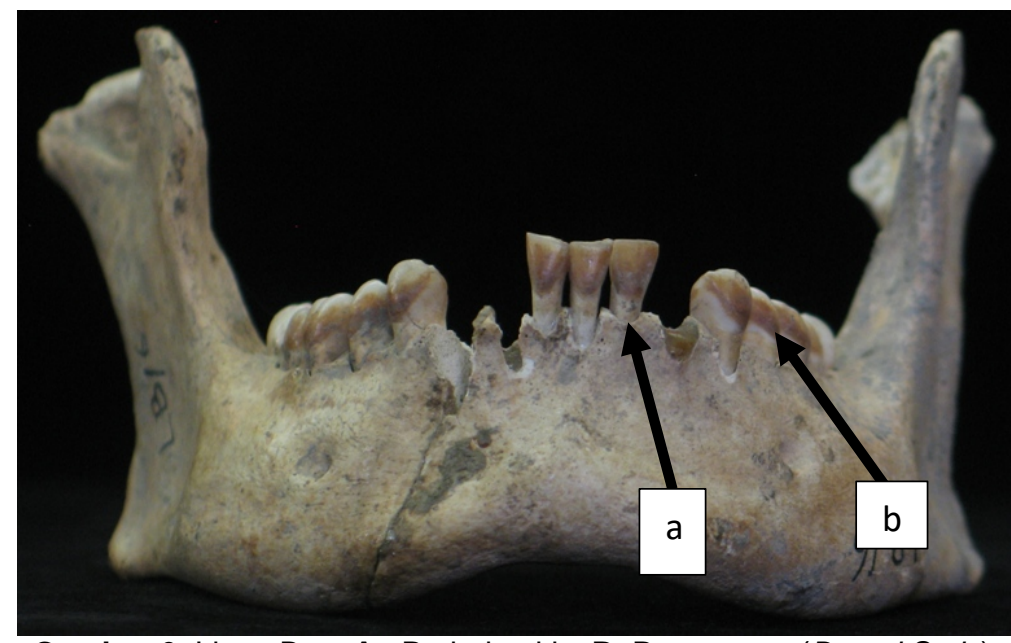

Gambar 6. Liang Bua. A= Periodontitis, B=Pewarnaan (Dental Stain) (Sumber: Foto Koleksi Pribadi)

Tabel 3 adalah gambaran secara ringkas patologi dan dental staining pada individu dari Lewoleba dan Liang Bua. Tabel 3 menunjukkan bahwa sebanyak 8 individu (80\%) mengalami praktik pencabutan gigi, yaitu gigi incisivus lateral pada maxilla. Bahwa seluruh individu mempraktekkan pencabutan/ablasi mengindikasikan bahwa masyarakat Lewoleba dan Liang Bua memiliki budaya yang kurang lebih sama. Diduga bahwa pencabutan adalah ekspresi dari sistem kepercayaan sebagai tanda atau ritus kedewasaan, terutama tanda bagi seseorang yang sudah memasuki masa/usia perkawinan (Koesbardiati dkk., 2015, hlm. 54). 
Tabel 3. Patologi dan Modifikasi Gigi

Pada Masyarakat Prasejarah Lewoleba dan Liang Bua

\begin{tabular}{lllll}
\hline No. & Individu & Dental Stain & \multicolumn{1}{c}{ Patologi Gigi } & $\begin{array}{c}\text { Modifikasi } \\
\text { Gigi }\end{array}$ \\
\hline 1. & LL I.1 & \multicolumn{1}{c}{ ? } & Atrisi & ? \\
2. & LL I.2 & Dental staining & Atrisi, kalkulus, periodontitis, AMTL & Pencabutan \\
3. & LL I.3 & Dental staining & Atrisi & Pencabutan \\
4. & LL I.4 & Dental staining & Atrisi, kalkulus, periodontitis & Pencabutan \\
5. & LL I.5 & Dental staining & Atrisi, AMTL, periodontitis & Pencabutan \\
6. & LB/1 & Dental staining & Atrisi, karies, kalkulus, periodontitis & Pencabutan \\
7. & LB/2 & Dental staining & Atrisi, karies, kalkulus, periodontitis & Pencabutan \\
8. & LB/3 & Dental staining & Atrisi, abses, periodontitis, AMTL & Pencabutan \\
9. & LB/5 & Dental staining & Atrisi, karies, kalkulus & ? \\
10. & LB/6 & Dental staining & Atrisi & Pencabutan \\
\hline & & & Sumber: Data Pribadi &
\end{tabular}

\section{DISKUSI DAN PEMBAHASAN}

Berdasar Tabel 3 menunjukkan bahwa 9 dari 10 individu (90\%) yang diamati memiliki dental staining pada gigi geliginya. Satu individu tidak dapat diamati karena kondisi tengkorak yang tidak memungkinkan untuk mengamati gigi geliginya. Dengan kata lain bahwa hampir seluruh individu yang diamati mengindikasikan mengkonsumsi sirih pinang. warna bergradasi dari yang tipis samar hingga pekat berwarna merah kecoklatan. Tingkat kekuatan gradasi warna diduga dipengaruhi oleh intensitas mengunyah dan lama menggunakan sirih pinang.

Tradisi mengunyah sirih pinang pada masyarakat Nusa Tenggara Timur masa kini adalah sirih pinang lengkap, yaitu sirih pinang yang terdiri dari darun sirih, buah pinang kering (yang lebih disukai) dan kapur yang berasal dari kerang dan karang laut yang dibakar lalu ditumbuk halus. Kadangkala masyarakat menggunakan bunga sirih sebagai pengganti daun sirih. Kebiasaan ini sudah menjadi bagian kehidupan masyarakat. Sirih pinang dapat ditemui di pasar sebagai bahan yang sangat mudah dijumpai dan banyak dijual, mengindikasikan bahwa kebutuhan terhadap bahan tersebut juga tinggi.

Sirih pinang memiliki kedudukan yang tinggi pada budaya Nusa Tenggara Timur hingga kini. Sirih pinang harus dihadirkan dalam setiap kegiatan ritual adat, maupun dalam kegiatan sosial lainnya. Tidak ada perbedaan jenis kelamin dalam menggunakan sirih pinang. Baik laki-laki maupun perempuan sangat menyukai sirih pinang. Bahkan anak-anak boleh dan sudah memanfaatkan sirih pinang. Menurut kepercayaan umum, sirih pinang dapat menyembuhkan berbagai penyakit, misalnya kembung, sakit perut, mencegah karies dan menguatkan gigi. Pengobatan tradisional ini biasanya dilakukan oleh seorang penyembuh tradisional yang dipercaya memiliki kekuatan supranatural. Metode pengobatan biasanya dengan mengunyah sirih pinang lalu memborehkan ke perut atau bagian yang sakit, cara lain adalah menyemburkan kunyahan sirih pinang ke bagian yang sakit. Oleh karena itu seringkali penyembuh tradisional disebut sebagai dukun sembur. 
Tradisi mengunyah sirih pinang ini diduga berasal dari budaya yang dibawa oleh masyarakat penutur rumpun Bahasa Austronesia. Fitzpatrick, dkk. (2003, hlm. 59-60), menjelaskan bahwa kebiasaan mengunyah sirih pinang tersebar seiring dengan persebaran masyarakat penutur Austronesia sekitar 6000 tahun lalu. Bukti persebaran sirih pinang ini dapat ditemui pada masyarakat Palau, Mikronesia sekitar 3000 BP. Di Indonesia, gelombang migrasi Austronesia bergerak dari wilayah barat Indonesia menuju ke timur Indonesia. Gelombang migrasi Austronesia lain datang dari utara menuju ke selatan. Hal ini menjadikan Nusa Tenggara Timur sebagai melting pot seluruh migrasi Austronesia (Lansing dkk., 2011, hlm. 263-264; Mona dkk., 2009, hlm. 1865-1866; Koesbardiati, 2014, hlm. $8)$.

Berdasarkan aspek patologi seperti tercantum pada Tabel 3., teridentifikasi patologi pada gigi geligi masyarakat prasejarah Lewoleba dan Liang Bua, yaitu karies (30\%), kalkulus (50\%), AMTL (30\%), Abses (10\%), periodontitis $(60 \%)$, dan atrisi $(100 \%)$. Aktivitas mengunyah berarti terjadi kontak antara gigi dengan gigi. Semakin keras bahan yang dikunyah semakin berat beban oklusal gigi. Efek dari mengunyah adalah terjadinya atrisi. Semakin lama dan semakin kuat beban gigi semakin kuat akibat yang ditimbulkan, dalam hal ini atrisi. Mengunyah sirih pinang dengan bahan lengkap (daun sirih, buah pinang dan kapur, terutama jika buah pinang yang dikonsumsi adalah jenis yang dikeringkan) akan membebani bidang oklusal gigi.

Sirih pinang memang bukan satu-satunya penyebab atrisi, melainkan juga dipengaruhi oleh bahan makanan lain yang mungkin kurang bersih sehingga masih membawa butiran partikel (misalnya debu, pasir) yang mempercepat keausan gigi. Di kawasan Indonesia sirih pinang dihadirkan pada saat ritual atau saat berkumpul bersama. Perbedaan kesempatan/acara mempengaruhi durasi dan intensitas pengunyahan. Kadangkala perbedaan jenis kelamin berhubungan dengan durasi dan intensitas mengunyah. Hal tersebut didukung oleh penelitian yang telah dilakukan Hsiao dkk. (2014, hlm. 137), bahwa perempuan lebih banyak mengunyah sirih pinang saat aktivitas tradisional dan acara sosial.

Lebih jauh, Hsiao dkk. (2014, hlm. 137), menjelaskan bahwa laki-laki lebih menikmati sirih pinang saat bekerja. Mengunyah sirih pinang menghasilkan efek menenangkan. Artinya, dalam proses mengunyah dilakukan secara intensif dan dalam durasi lama. Jika sirih pinang bermakna tinggi dalam kehidupan social, dapat dipastikan bahwa penggunaan sirih pinang dilakukan dalam frekuensi yang tinggi. Intensitas pengunyahan ini diduga berakibat pada atrisi gigi. Seluruh individu yang diamati (100\%) dalam penelitian ini menunjukkan bukti adanya atrisi. Sekalipun sirih pinang bukan satu-satunya penyebab atrisi, namun dalam hal ini mengindikasikan bahwa konsumsi sirih pinang berpotensi menyebabkan atrisi gigi.

Ketika bahan sirih pinang bercampur di mulut, akan mengeluarkan efek cholinergic yang mempengaruhi produksi saliva (ludah) secara berlebihan. Produksi saliva dapat menghindarkan gigi dari karies dan dental kalkulus. Karena saliva berlebih dapat membersihkan gigi dari sisa makanan dan sisa bahan sirih pinang. Hal ini semakin optimal jika dibarengi dengan menjaga kebersihan mulut. Pada masyarakat prasejarah, kebersihan mulut bisa jadi dilakukan dengan cara sederhana sesuai dengan perkembangan pengetahuan local. Campuran sirih 
pinang dan saliva akan membentuk kalkulus yang akan terus bertambah seiring dengan lamanya kebiasaan tersebut dilakukan. Kapur sirih dapat memperparah timbunan kalkulus pada gigi. Dalam studi kasus di dalam laboratorium yang menguji masyarakat modern, Giri dkk. (2014, hlm. 57-60), menyebutkan bahwa bertambahnya timbunan kalkulus dapat merusak jaringan gusi dan membrane periodontal. Arecoline sebagai bagian utama dari alkaloid menghalangi pertumbuhan sel dan sintesis kolagen. Akibat lain menurut Giri dkk. (2014, hlm. 57-60), adalah respon inflamasi yang mempengaruhi kesehatan jaringan periodontal dan melonggarkan gigi dari soketnya. Efek ini bertambah parah jika campuran sirih pinang ditambah dengan penggunaan tembakau.

Giri dkk. (2014, hlm. 57-60), menyimpulkan bahwa timbunan kalkulus sebagai hasil produksi saliva yang berlebihan dan meningkatnya garam kalsium dalam mulut yang berasal dari kapur sirih mengakibatkan kerusakan jaringan periodontal. Hasil penelitian Hsiao (2014, hlm. 133-140) dan Samnieng (2012, hlm. 107-111) mendukung pendapat Giri dkk. (2014, hlm. 57-60), dimana timbunan kalkulus yang tidak terkontrol dapat memperparah jaringan periodontal dibanding dengan kandungan zat aktif sirih pinang. Ling dkk. (2001, hlm. 364369), dalam studinya menyebutkan bahwa sirih pinang dapat meningkatkan inflamasi pada gusi yang akan berakibat pada kerusakan jaringan periodontal. Semakin parah jaringan periodontal rusak, semakin besar peluang untuk terjadinya AMTL. Dalam hal ini AMTL adalah efek terparah dari patologi gigi karena AMTL berarti kehilangan gigi, yang berarti pula fungsi apparat kunyah akan terganggu.

Sebanyak 10 individu yang diamati menggunakan sirih pinang, semuanya mengalami atrisi (100\%). Sebanyak 5 individu (50\%) mengalami dental kalkulus dan sebanyak 6 individu $(60 \%)$ mengalami periodontitis. Jumlah individu yang mengalami AMTL sebanyak 3 individu (30\%). Dari individu yang mengalami AMTL juga diidentifikasi mengalami periodontitis. Individu yang mengalami periodontitis juga mengalami dental kalkulus. Hal ini mengindikasikan bahwa sirih pinang berpengaruh terhadap timbulnya beberapa patologi gigi seperti atrisi, sebagai efek paling umum disusul kalkulus, periodontitis dan AMTL sebagai akibat lanjutan. Karies ditemui sebanyak 30\% dan abses sebanyak $10 \%$. Bisa jadi bahan aktif sirih pinang berkhasiat menghambat terjadinya karies. Penelitian lanjut sangat diperlukan untuk memahami lebih dalam tentang patologi pada temuan arkeologis, terutama yang terkait dengan kebiasaan mengunyah sirih pinang, mengingat bahwa sirih pinang adalah tradisi lama yang telah dilakukan sejak sekurang-kurangnya masa neolitik.

\section{KESIMPULAN}

Sirih pinang disebut sebagai bahan adiktif yang dapat memberi sensasi kenyamanan bagi pemakainya. Oleh karena itu sirih pinang dimanfaatkan hingga sekarang. Bahkan secara budaya penggunaan sirih pinang dipercaya dapat menyembuhkan banyak penyakit. Di sisi lain, sirih pinang disebut sebagai penyebab banyak patologi gigi dan mulut. Penelitian ini mendeskripsikan 
hubungan konsumsi sirih pinang dengan timbulnya patologi gigi. Dari 10 individu anggota masyarakat prasejarah Liang Bua dan Lewoleba menunjukkan dental staining (pewarnaan) yang mengindikasikan bahwa kedua populasi masyarakat tersebut menggunakan sirih pinang. Hal ini dikuatkan bahwa warna atau dental stain ditemukan hingga gigi molar, yaitu gigi deretan posterior (belakang) pada maxilla maupun mandibula. Dengan kata lain ada aktifitas disengaja yang dilakukan oleh pengguna sirih pinang. Variasi gradasi warna atau tebal tidaknya warna diduga dipengaruhi oleh intensitas dan lama mengunyah. Selain itu tembakau yang digunakan untuk meratakan saliva berisi hasil kunyahan sirih pinang membantu pewarnaan seluruh permukaan gigi geligi. Mengingat banyaknya macam bahan sirih pinang, sirih pinang berpotensi menimbulkan atrisi. Sekalipun demikian sirih pinang bukan satu-satunya bahan yang menimbulkan atrisi, bahan makanan atau apapun yang dikunyah berpotensi menimbulkan atrisi. Hasil pengamatan menunjukkan bahwa individu yang teridentifikasi memiliki atrisi, juga memiliki dental kalkulus, periodontitis dan bahkan AMTL. Hal ini mengindikasikan adanya efek berantai dari sebuah kebiasaan mengunyah sirih pinang.

Jika dibandingkan dengan pendapat umum saat ini, bahwa mengunyah sirih pinang berefek menguatkan gigi geligi, misalnya dalam pengertian gigi tidak berlubang atau karies, maka hasil penelitian ini menunjukkan bahwa sirih pinang diduga menyebabkan patologi gigi geligi. Hal ini diduga dipengaruhi oleh lama menggunakan sirih pinang, intensitas menggunakan sirih pinang dan masalah kebersihan mulut. Seperti telah diuraikan di atas bahwa sirih pinang bisa jadi menguatkan gigi. Tetapi penggunaan dalam jangka waktu yang lama dan intensitas yang sering dalam mengunyah sirih pinang dapat mengakibatkan kalkulus. Kalkulus ini yang kemudian berpengaruh terhadap periodontitis dan berakhir dengan AMTL. 


\section{DAFTAR PUSTAKA}

Ali, N.S. \& Kuwaja, A.K. (2011). Betel nut (Areca catechu) usage and its effects on health. Dalam Nuts \& Seeds in Health $\mathcal{E}$ Disease Prevention (hlm.197-204).

Aufderheide, A.C. \& Rodriguez-Martin, C. (1998). The Cambridge encyclopedia of human pathology. Cambridge University Press.

Atmosudiro, S. (1994). Gerabah prasejarah di Liang Bua, Melolo dan Lewoleba: Tinjauan teknologi dan fungsinya. (Disertasi). Yogyakarta: Fakultas Ilmu Budaya, UGM.

Giri, D. K., Pundapur, P., Bhat, K.M., \& Maharjan, I.K. (2014). Betel Nut Chewing associated with severe periodontitis. Health Renaissance, 12(1), 57-60.

Fritzpatrick, S.M., Nelson, C.G., \& Reeves, R. (2003). The prehistoric chewing of betel nut (Areca catechu) in Western Micronesia. PeopleECulture in Oceania $19,55-65$.

Hsiao, C.-N., Chun-Chan, T., Tien-Yu, S., \& Ko, C.E. (2014). Relationship between betel quid chewing and radiographic alveolar bone loss among Taiwanese aboriginals: a retrospective study. BMC Oral Health, 14, 133.

Hsiao, C.-N., Ko, C.E., Shieh, T.Y., \& Hong-Sen, C. (2015). Relationship between areca nut chewing and periodontal status of people in a typical aboriginal community in Southern Taiwan. Journal of Dental Sciences, 10, 300-308.

Javed, F., Tenenbaum, H.C., Nogueira-Filho, G., Qayyun, F., Correa, F.O.B., AlHezaimi, K., \& Samaranayake, L. (2013). Severity of periodontal disease in individu chewing betel quid with and without tobacco. The American journal of the medical sciences, Vol. 346, 4.

Koesbardiati, T., Murti, D.B., \& Suriyanto, R.A. (2015). Cultural dental modification in prehistoric population in Indonesia. 2015. Bull Int Assoc Paleodont, Vol. 9 (2), 52-60.

Koesbardiati, T. (2014). Rekonstruksi alam dan kehidupan berdasarkan rangka manusia. Disampaikan sebagai pidato dalam rangka peringatan Dies Natalis ke 60 Universitas Airlangga.

Lansing, J.S., Murray, P.C., De Vet, T.A., Downey, S.S., Hallmark, B., \& Sudoyo, H. (2011). An ongoing Austronesian expansion in Island Southeast Asian. Journal of Anthropological Archaeology, 30, 262-272. 
Lie, G.L. (1965). Paleoanthropological results of the excavation at the coast of Lewoleba, Isle of Lomblen. Anthropos, 60, 609-624.

Ling, L.-J., Hung, S.-L., Tseng, S.-C., Chen, Y.-T., Chi, L.-Y., Wu, K.-M., \& Lai, Y.L. (2001). Association between betel quid chewing, periodontal status and periodontal pathogens. Oral Microbiology and Immunology, Vol.16, issue 6.

Mona, S., Grunz, K.E., Pakendorf, B., Castri, L., Sudoyo, H., Marzuki S., Barnes, R.H., Schmidtke, J., Stoneking, M., \& Kayser, M. (2009). Genetic admixture history of eastern Indonesia as revealed by Y-Chromosome and mitochondrial DNA Analysis. Mol Biol Evol, 26(8), 1865-1866.

Murti, D.B.M. (2011). Beberapa patologi pada seri tengkorak dan gigi dari situs Liang Bua, Lewoleba dan Melolo: suatu tinjauan bioarkeologis dan rekomendasi konservasinya. (Tesis). Yogyakarta: Fakultas Ilmu Budaya, UGM.

Oxenham, M. (2002). Identification of areca catechu (betel nut) residues on the dentition of bronze age inhabitants of Nui Nap, Northern Vietnam. Journal of Archaeological Science, 29, 909-915.

Public Health Law Center. (2017). Risks of betel quid tobacco use. www.publichealthlawcenter.org.

Wei, P., Yu-Jie, L., Na, W., Tao, S., Xiao-Yan, H., \& Yong-Xian, G. (2015). Areca catechu L.(Arecaceae): a review of its traditional uses, botany, phytochemistry, pharmacology and toxicology. Journal of Ethnopharmacology, 164, 340-356.

Samnieng, P. 2012. Assosiation of betel quid chewing with oral complaint and oral health status in elderly Thai. International Journal of Clinical Prevention Denstistry, Vol. 8:2, 107-111.

WHO. (2012). Review of Areca (Betel) Nut and Tobacco use in the Pacific: a technical report.

Zumbroich, T.J. (2007-2008). The origin and diffusion of betel chewing: a synthesis of evidence from South Asia, Southeast Asia and beyond. eJournal of Indian Medicine, Vol. 1, 87-140. 